\title{
Efficacy of measures to control caprine arthritis-encephalitis in dairy herd with high clinical and serological prevalence
}

\section{Eficácia das medidas de controle da artrite-encefalite caprina em rebanho leiteiro com alta prevalência clínica e sorológica}

\author{
Jefferson Filgueira Alcindo ${ }^{1 *}$; Sara Vilar Dantas Simões ${ }^{2}$; Raymundo Rizaldo \\ Pinheiro $^{3}$; Renato Mesquita Peixoto ${ }^{4}$; Alice Andrioli; ${ }^{3}$ Érica Beatriz Schultz ${ }^{5}$; \\ Leydson Formiga Feitosa ${ }^{6}$
}

\begin{abstract}
Highlights:
First caprine arthritis-encephalitis control program in a commercial herd.

Limitations in the application of disease control measures.

Necessary measures to minimize infection of young animals.
\end{abstract}

\begin{abstract}
This study examined the effectiveness of control measures for caprine arthritis-encephalitis in a herd with 431 dairy goats in an intensive rearing system. All animals older than six months were initially tested by agar gel immunodiffusion (AGID) and separated into seropositive and seronegative. Control measures were implemented for two years and ten months. Five serological examinations were subsequently performed - two by AGID and three by the Western Blot (WB) technique. In these tests, animals that tested negative in the previous serological examination were evaluated along with those older than six months which had not yet been examined. The effectiveness of control was evaluated based on the incidence of the disease. Seroconverted animals were stratified according to age, physiological status and dam serology. For the effect of time, logistic regression was performed at the $5 \%$ significance level, with values converted into likelihood. General incidence and incidence as a function of age and physiological status were evaluated by analysis of variance, with means compared by Tukey's test at $5 \%$ significance. The ratio test was used for incidence and physiological status, and the agreement between the AGID and WB tests was determined by the Kappa coefficient. Animals that seroconverted and were born to positive dams were compared with those born to dams negative at birth by the Chi-square test, and the same was applied for the number of discarded animals. Initially, 54.24\% (179/330) positive and 257 seroconverted animals were identified after the start of control. Higher incidence occurred in the animals aged between 13 and 36 months and in lactating does. Seroconversions among offspring of seropositive
\end{abstract}

\footnotetext{
1 Discente, Curso de Doutorado do Programa de Pós-Graduação em Ciência Animal, Faculdade de Medicina Veterinária de Araçatuba, FMVA, Araçatuba, SP, Brasil. E-mail: jefferson.alcindo@yahoo.com.br

2 Prof ${ }^{\text {a }}$ Dra $^{\mathrm{a}}$, Departamento de Ciências Veterinárias, Universidade Federal da Paraíba, UFPB, Areia, PB, Brasil. E-mail: saravdsimoes@gmail.com

3 Pesquisadores, Empresa Brasileira de Pesquisa Agropecuária, EMBRAPA CAPRINOS E OVINOS, Sobral, CE, Brasil. E-mail: rizaldo.pinheiro@embrapa.br; alice.andrioli@embrapa.br

4 Dr., Empresa Brasileira de Pesquisa Agropecuária, EMBRAPA CAPRINOS E OVINOS, Sobral, CE, Brasil. Bolsista de Desenvolvimento Científico Regional do Conselho Nacional de Desenvolvimento Científico e Tecnológico (DCR-CNPq/ FUNCAP), nível C, Brasília, DF. E-mail: renatomiraima@gmail.com

$5 \operatorname{Prof}^{\mathrm{a}} \mathrm{Dr}^{\mathrm{a}}$, Departamento de Produção Animal, Universidade Federal Rural do Rio de Janeiro, UFRRJ, Seropédica, RJ, Brasil. E-mail: ericabeatrizschultz@gmail.com

6 Prof. Dr., Departamento de Clínica, Cirurgia e Reprodução Animal, Faculdade de Medicina Veterinária de Araçatuba, FMVA, Araçatuba, SP, Brasil. E-mail: leydsonf@fmva.unesp.br

Author for correspondence
} 
dams were higher than in the offspring of seronegative dams $(\mathrm{p}<0.001)$. High infection rates were identified in the sires. The obtained results were not satisfactory, as the measures did not help to prevent new cases, indicating that there are moments of infection yet to be elucidated. On farms that aim to control the disease, the following measures are required in addition to those already recommended: use of diagnostic tests with less frequency; application of high-sensitivity tests in the offspring; immediate separation of kids from dams at birth; separation of kids according to the serological status of the dams; inclusion of kids from unsupervised births in the group of kids from positive dams; and keeping positive and negative animals on different farms or greatly distanced. In herds for which there is an intention to establish control, it is important to determine whether the productive losses associated with the disease are greater than the costs of implementing more efficient measures.

Key words: Goats. Lentiviruses. Epidemiology. Control program. Brazil.

\section{Resumo}

Avaliou-se a eficácia das medidas de controle para a artrite-encefalite caprina em rebanho com 431 caprinos leiteiros em regime intensivo de criação. Todos os animais com idade superior a seis meses foram inicialmente testados por imunodifusão em gel de ágar (IDGA) e soropositivos e soronegativos separados. Durante dois anos e dez meses medidas de controle foram instituídas. Cinco testes sorológicos foram posteriormente realizados, dois por IDGA e três por Western Blot (WB). Nesses testes eram avaliados os animais negativos na sorologia anterior e acrescidos os com mais de seis meses, ainda não avaliados. A eficácia do controle foi avaliada pela incidência da enfermidade. Animais que soroconverteram foram estratificados quanto a idade, estado fisiológico e sorologia das progenitoras. Para o efeito do tempo foi realizado a regressão logística a 5\% de significância, convertidos em razão de probabilidades. A incidência geral e incidência em função da idade e estado fisiológico foram avaliadas pela análise variância, comparando as médias pelo teste Tukey a $5 \%$ de significância. O teste de proporções foi utilizado para incidência e estado fisiológico, e a concordância entre os testes IDGA e Wb realizada através do coeficiente Kappa. Os animais que soroconverteram e eram nascidos de progenitoras positivas foram comparados com aqueles de progenitoras negativas ao parto pelo teste de Qui-quadrado, assim como o número de animais descartados. Inicialmente identificou-se 54,24\% (179/330) de animais positivos e 257 soroconverteram após início do controle. Incidências maiores ocorreram nos animais entre 13 e 36 meses e nas lactantes. Soroconversões em crias de progenitoras soropositivas foram maiores que nas de progenitoras soronegativas $(\mathrm{p}<0,001)$. Altas taxas de infecção foram identificadas nos reprodutores. Os resultados obtidos não foram satisfatórios, pois as medidas não contribuíram para evitar novos casos, demonstrando que existem momentos de infecção que precisam ser elucidados. Nas propriedades que intencionam controlar a enfermidade, além das medidas já recomendadas, é necessário utilizar testes diagnósticos com menor periodicidade; teste de alta sensibilidade nos animais jovens; realizar imediata separação das crias das progenitoras ao nascimento; separar as crias de acordo com o status sorológico das progenitoras; incluir as crias provenientes de partos não acompanhados no grupo de crias de progenitoras positivas e manter animais positivos e negativos em propriedades diferentes ou com grande distanciamento. É importante avaliar, nos rebanhos em que há a intenção de se estabelecer um controle, se as perdas produtivas associadas a enfermidade são maiores que os custos da implementação de medidas mais eficientes.

Palavras-chave: Caprinos. Lentiviroses. Epidemiologia. Programa de controle. Brasil.

\section{Introduction}

The etiologic agent of caprine arthritisencephalitis (CAE) belongs to the family Retroviridae, genus Lentivirus (International Committee on Taxonomy of Viruses [ICTV], 2019), and is characterized by being a single-stranded RNA virus that replicates by forming reverse transcription-dependent DNA. It can integrate into the genome of the host, infect macrophages and monocytes and induce persistent infection despite the production of antibodies (Reilly, Baird, 
\& Pugh, 2012). Once infected, goats may remain with subclinical infection or develop clinical manifestations, which include arthritis, progressive paresis or another neurological disorder, hardening of the udder with decreased milk production, chronic interstitial pneumonia or progressive weight loss (Smith \& Sherman, 2009).

The integration of proviral DNA into the cell genome, which allows the virus to escape the host's defense mechanisms and preserve its genome; the fact that the host is unable to develop a curative immune response due to the multiplication of immune system cells (Narayan, Joag, Chebloune, Zink, \& Clements, 1997; Callado et al., 1999); and the high rate of mutation during the replication process (Cheevers, McGuire, Norton, CorderyCotter, \& Knowles, 1993) promote the persistence of the infection in its hosts. Late seroconversion, another factor related to the virus, also makes it difficult to control the disease in control programs in which serological methods are used to detect reactive animals (Rimstad, East, De Rock, Higgins, \& Pedersen, 1994). The above-described factors demonstrate that once the disease is introduced in a herd, the risk of other animals becoming infected is always present and requires strict control measures.

Transmission occurs mainly in the first months of age, through ingestion of colostrum/milk from infected animals (Adams, Klevjer-Anderson, Carlson, \& McGuire, 1983). Perinatal infection can also occur intrauterinely, through vaginal contact and through the exposure of the offspring to secretions originating from the dam, such as saliva and nasal secretions, which usually occurs when the dam licks the newborn (Rowe \& East, 1997). Goats can also excrete the CAE virus in saliva in its pro-viral form, and cells from this fluid are likely to produce infectious virus (Souza et al., 2015). Venereal transmission has been discussed, and semen artificially infected with the CAE virus was considered a probable route of disease transmission to the doe (Souza et al., 2013). The virus has also been detected in water and air, which supports the recommendation of segregating infected animals. Because water can also play an important role in the transmission of the disease, it is also a factor to be observed (Villoria et al., 2013). Based on the knowledge of its transmission routes, several risk factors have been identified and control and prevention methods presented (Rowe \& East, 1997; Peterhans et al., 2004; Reina et al., 2009).

Despite the available information on the control of $\mathrm{CAE}$, the disease situation in Brazilian goat herds is worrying. After the first record of the disease, by Moojen, Soares, Ravazzolo, Pizzol and Gomes (1986) in the state of Rio Grande do Sul, studies have been carried out and shown that the virus has been spreading in Brazil with frequencies that vary according to the type of exploitation, rearing system and breeds used: São Paulo $=15.1 \%$ (30/199) (Lara et al., 2013) to $34.9 \%(96 / 275)$ (Madureira \& Gomes, 2007); Minas Gerais $=49.5 \%$ (531/1072) (Nascimento-Penido, Penido, Galinari, Heinemanns, \& Leite, 2017); Rio de Janeiro = 14.1\% (79/562) (Cortez-Moreira, Oelemann, \& Lilenbaum, 2005); Sergipe $=5.03 \%(34 / 675)$ (Rizzo et al., 2018); Bahia $=0.29 \%(2 / 693)($ Lima et al., 2013a); Ceará $=40.73 \%(101 / 248)$ (Melo $\&$ Franke, 1997); Pernambuco $=18.01 \%(76 / 422)$ (Silva et al., 2012).

Pinheiro, Ximenes, Andrioli and Texeira (2009), Lima et al. (2013b) and Azevedo et al. (2017) identified a total of 73 serological surveys carried out in Brazil. Some studies have shown the economic losses associated with the disease and its risk factors (Alves et al., 2017; Rizzo et al., 2018). In Brazil, only two studies have been found on control methods in naturally infected herds (Stachissini et al., 2007; Rodrigues et al., 2018). In other countries where the occurrence of CAE is also worrying, studies have been developed aiming at the control and/or eradication of the disease (Péretz, Bugnard, \& Calavas, 1994; Nord, Løken, \& Orten, 1998; Kaba et al., 2011; Konishi et al., 2011; Gufler, 2013; Tavella et al., 2017). In these countries, producers usually adopt control programs voluntarily, based 
on periodic serological tests with separation and/ or elimination of seroreactive animals and the use of management practices to prevent and control the agent.

In view of the importance of further investigations aiming at the control of CAE in Brazil, the present study was proposed to evaluate the effectiveness of control measures in a commercial herd of dairy goats with proven occurrence of CAE and the impacts of adopting these measures on the incidence of the disease. The results obtained in this study may help producers and professionals define practices to be implemented in infected herds.

\section{Material and Methods}

The study was developed between August 2014 and August 2017 in a dairy goat herd in the municipality of São José do Rio Preto, northwestern São Paulo State, Brazil. On the farm, 431 animals of the Saanen and Alpine breeds, of different age groups, were reared intensively.

At the onset of the experiment, 159 does were lactating. These were milked mechanically, only once daily, observing the hygiene rules for mastitis prophylaxis. The daily milk yield was around 200 L, which was used for the production of cheese or yogurt, or sold after pasteurization. Lactating does were kept in elevated wood pens and allowed access to a solarium with masonry floors. The does were divided into lots of 30 animals and kept in stalls 2 $\mathrm{m}$ wide $\times 10 \mathrm{~m}$ long, which provided an area of 0.6 $\mathrm{m}^{2}$ per animal.

Ten sires were part of the herd and another seven were acquired during the study. Unlike the dams, all males were acquired from other farms and were only introduced in the herd after a negative agar gel immunodiffusion test (AGID). Does were conceived by natural service, with three breeding seasons occurring throughout the year. In each breeding season, the sires were placed in the stalls of the selected does, where they remained for a period corresponding to two reproductive cycles (42 days). Male kids were sold after birth and doe kids were kept in cages with capacity for three animals, where they remained for 50 days and after which time they were transferred to larger cages with capacity for 20 animals, where they stayed 20 days, on average. Subsequently, the does were allocated to the post-weaning stalls until reaching an ideal weight for service (32 to $35 \mathrm{~kg}$; around 11 months). Then, they were transferred to stalls close to those of the lactating does to receive the males for service, where they remained until kidding.

The entire herd received the same feed, which consisted of hay, maize silage and concentrate and was offered in balanced amounts according to the animal category. A mineral mixture was added to the concentrate and mineral salt was freely available in troughs to which the animals had daily access. As for sanitary management, the herd received two vaccines: the first, against caseous lymphadenitis, in newly weaned animals, with a monthly boost; and the second, against clostridiosis, which was administered in animals aged two months or older, with a monthly boost in those which were vaccinated for the first time and a repetition at every four months in all animals.

Before the study began, meetings were held with employees and other persons linked to the farms to disseminate information about caprine arthritis-encephalitis and control. The presented measures were based on the recommendations of the Ministry of Agriculture, Livestock and Supply (Portaria $\left.n^{\circ} 103,2004\right)$, which included: i) segregation of positive and negative animals after initial serological examination; ii) single use of needles, syringes and blades; iii) disinfection of the equipment used to identify and tattoo the animals with $70^{\circ}$ alcohol; iv) gradual disposal of positive animals; v) introduction of new animals only after negative serological evidence for CAE; vi) milking negative animals before positive animals; vii) separation of kids from dams after birth and supply of cow colostrum, thermized goat milk (56 
${ }^{\circ} \mathrm{C} / 1 \mathrm{~h}$ ), or substitutes. Additional control measures that were presented because they were considered important were the use of positive sires or sires that would come to seroconvert during the study period only to mount does with the same serological status; and use of bandages on the teats of pregnant does on the 5th day preceding the estimated date of kidding, to prevent ingestion of colostrum in unsupervised births.

To identify seroreactive animals and segregate the herd into positive and negative, blood was collected from all animals older than six months for the initial serological test by AGID, aiming to avoid interference from colostral antibodies. Positive and negative animals were separated in accordance with the recommendations of Adams et al. (1983), using existing facilities on the farms, which had stalls separated by a $2-m$ central corridor. Subsequently, five new serological examinations were performed on the animals identified as negative in the previous test. Animals older than six months which had not yet been evaluated were included in each analysis. The animals were tested twice by AGID and the Western Blot (WB) technique was performed in the last three tests, with the objective of using a method of greater sensitivity. The interval between the initial serological examinations and the first follow-up serological examinations was 211 days; between the first and the second, 253 days; between the second and third, 87 days; between the third and fourth, 238 days; and between the fourth and fifth, 245 days.

The effectiveness of the implemented control measures was evaluated based on the seroconversion rate during the study. Animals that seroconverted after the start of the control program were also evaluated to prevent those already infected at the beginning of the program from having seroconversion associated with inefficiency of the implemented control measures. The animals that seroconverted were stratified and analyzed according to their age, physiological status (dry and lactating does) and serological status of their mothers.
The agar gel immunodiffusion test was carried out in a laboratory licensed by MAPA (Ministry of Agriculture, Livestock and Supply) under registration number 9049, using commercial antigen, in accordance with the kit recommendations. Western blotting analyses were performed at the Clinical Pathology Laboratory at Embrapa Goat and Sheep, following Rodrigues et al. (2014).

To evaluate the effect of time on disease incidence, the data were converted into categorical form, where 0 was assigned for positive animals and 1 for negative animals. After this conversion, logistic regression analysis was performed using a generalized linear model with binomial distribution assuming 5\% significance, with the final results converted by the odds ratio. General incidence data as well as comparisons of positive cases regarding age and physiological status (dry and lactating) were subjected to tests of normality, additivity and homoscedasticity of variances. Next, analysis of variance was performed and Tukey's test at 5\% significance was applied to compare the means. The physiological status and incidence rate variables were evaluated using the ratio test. The agreement between the AGID and WB serological tests was measured with the same animals using the Kappa coefficient. Animals that seroconverted and were born to positive dams were compared with those whose mother was not reactive at the time of birth by the Chi-square test, and the same was done for the discarded animals. All data were analyzed using the R Core Team statistical program [R] (2018).

All experimental procedures were approved by the Ethics Committee on Animal Use (CEUA) of São Paulo State University, Faculty of Dentistry of Araçatuba (approval no. 00094-2016).

\section{Results}

The initial serological examinations was carried out on 330 of the 431 animals on the farm, as the others were less than six months old, and revealed $54.24 \%(179 / 330)$ of positive animals. 
New seroconversions were identified in all five prevalence of $50.72 \%$ was obtained at the end of subsequent serological tests (Table 1), and a the study.

Table 1

Incidence of caprine arthritis-encephalitis in five serological tests performed after the beginning of the disease control program in a commercial herd, São José do Rio Preto/SP

\begin{tabular}{cccccc}
\hline Day of testing & Serology & Test used & $\begin{array}{c}\text { Number of tested } \\
\text { animals }\end{array}$ & $\begin{array}{c}\text { Number of positive } \\
\text { animals }\end{array}$ & $\begin{array}{c}\text { Incidence } \\
(\%)\end{array}$ \\
\hline $03 / 26 / 2015$ & 1 & AGID $^{1}$ & 178 & 51 & 28.66 \\
$12 / 04 / 2015$ & 2 & AGID & 196 & 46 & 23.47 \\
$02 / 29 / 2016$ & 3 & WB $^{2}$ & 189 & 16 & 8.47 \\
$10 / 24 / 2016$ & 4 & WB & 224 & 62 & 27.68 \\
$06 / 26 / 2017$ & 5 & WB & 253 & 82 & 32.42 \\
\hline
\end{tabular}

${ }^{1}$ Agar gel immunodiffusion

2 Western blot.

The sum of new positive cases identified in each serological examination totaled 257 animals, 168 of which $(65.36 \%)$ were born after the start of the control program. There were no differences in incidence rates between the first and second tests ( $p=0.2534$ ); however, the number of animals that seroconverted was lower in the third in relation to the fourth test $(p=0.0001)$ and increased again in the fourth serological test $(p=0.0001)$. No difference was detected between the fourth and fifth serological tests $(p=0.2612)$. Table 2 shows the age groups of the animals at the time when seroconversion was identified.

\section{Table 2}

Odds ratio and likelihood of seroconversion over time in goats subjected to a caprine arthritis-encephalitis control program in a commercial herd, São José do Rio Preto/SP

\begin{tabular}{cccccc}
\hline & Variable & Odds ratio & CI [ 95\%] & $p$ value \\
\hline & Time & $\mathbf{0 . 9 9}$ & {$[\mathbf{0 . 9 8 5 - 0 . 9 9 9 ]}$} & $\mathbf{0 . 0 0 1 8 8}$ \\
\hline Predicted likelihood & 211 & Time after adoption of preventive measures (days) \\
\hline Negative & 0.797 & 0.79 & 0.776 & 578 & 823 \\
Positive & 0.203 & 0.210 & 0.224 & 0.736 & 0.689 \\
\hline Observed & \multicolumn{7}{c}{0.264} & 0.311 \\
\hline Positive & 0.7134 & 0.7653 & 0.153 & 0.7232 & 0.6758 \\
Negative & 0.2866 & 0.2347 & 0.847 & 0.2768 & 0.3242 \\
\hline
\end{tabular}

Time was significant for the odds ratio (\%) of the animals presenting or not presenting with the disease. For each day after the adoption of the preventive measures, the likelihood of the goats becoming positive increased by $1 \%$ (Table 2 ). Accordingly, the likelihood of the animals remaining negative decreased over time (Figure 1). 


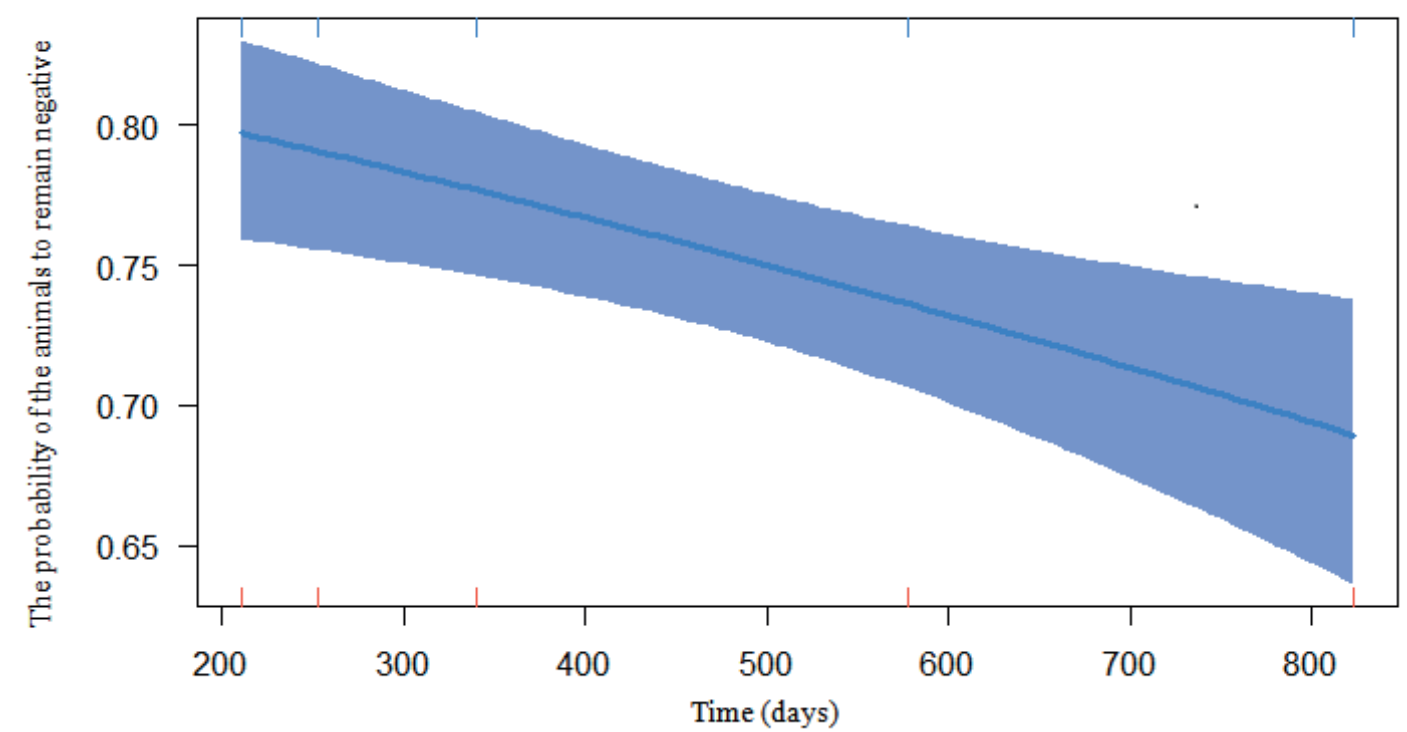

Figure 1. Likelihood of animals remaining seronegative over time in goats subjected to a caprine arthritis-encephalitis control program in a commercial herd, São José do Rio Preto/SP.

In serological examinations 1 and 2 , in which the animals were tested by AGID, no positive animals between the ages of six and 12 months were identified. In serological examinations 3, 4 and 5, in which WB was used as the serological test, positive animals were identified. Lower seroconversion rates were found in goats aged 6-12 months and over 36 months, when compared with those identified in animals aged between 13 and 36 months. The highest probability of the animal being negative (8.81) was identified in the age group of 6-12 months, and the lowest (0.098) between 25 and 36 months (Table 3 ).

\section{Table 3}

Age group of goats that seroconverted in serological tests performed after the start of a caprine arthritisencephalitis control program in a commercial herd, São José do Rio Preto/SP

\begin{tabular}{|c|c|c|c|c|c|}
\hline Serology & $>06-12 \quad(\%)$ & $13-24$ & $25-36 \quad(\%)$ & $37-48(\%)$ & $>48(\%)$ \\
\hline 1 & $0 \quad(0.00)$ & $28 \quad(54.90)$ & $18(35.29)$ & $4 \quad(7.84)$ & 1 (1.96) \\
\hline 2 & $0 \quad(0.00)$ & $23 \quad(50.00)$ & $19(41.30)$ & $(2.17)$ & $3(6.52)$ \\
\hline 3 & $3(18.75)$ & $5 \quad(31.25)$ & $5 \quad(31.25)$ & $(6.25)$ & $2(12.50)$ \\
\hline 4 & $12(19.35)$ & $27 \quad(43.54)$ & $22(35.48)$ & $(0.00)$ & 1 (1.61) \\
\hline 5 & $17 \quad(20.73)$ & $18 \quad(21.95)$ & $40(48.78)$ & $4 \quad(4.87)$ & $3 \quad(3.65)$ \\
\hline Overall mean & $11.76 \mathrm{~b}$ & $40.32 \mathrm{a}$ & $38.42 \mathrm{a}$ & $4.22 b$ & $5.24 b$ \\
\hline Odds ratio & 8.81 & 0.39 & 0.098 & 0.378 & 0.295 \\
\hline$p$-value & $<0.001$ & $<0.001$ & $<0.001$ & 0.020 & $<0.001$ \\
\hline
\end{tabular}

* letters in the row differ at 5\% significance by Tukey's test.

When the results obtained in the AGID and WB serological tests were contrasted, a Kappa index of 0.8702 was found (Table 4). 
Table 4

Results obtained with the AGID and WB techniques for testing samples, with respective Kappa index

\begin{tabular}{cccc}
\hline & AGID positive & AGID negative & Total \\
\cline { 2 - 5 } WB positive & 47 & 15 & 62 \\
WB negative & 4 & 158 & 162 \\
\hline Total & 51 & 173 & 224 \\
\hline \multicolumn{4}{c}{ Kappa $=0.8702$} \\
\hline
\end{tabular}

Considering seroconversions in lactating and dry does, a higher number was observed in serological examinations 1, 2 and 4 in the lactating animals (Table 5).

\section{Table 5}

Dry and lactating goats that seroconverted after the start of a caprine arthritis-encephalitis control program in a commercial herd, São José do Rio Preto/SP

\begin{tabular}{ccccccc}
\hline \multirow{2}{*}{ Serology } & \multirow{2}{*}{ Test } & \multicolumn{5}{c}{ N of seroconverted animals } \\
\cline { 3 - 7 } & AGID & 5 & $(9.8)$ & 46 & $(90.18)$ & $<0.0001$ \\
\hline 1 & AGID & 6 & $(13.04)$ & 40 & $(86.94)$ & $<0.0001$ \\
2 & WB & 6 & $(42.85)$ & 8 & $(57.13)$ & 0.0630 \\
3 & WB & 25 & $(40.98)$ & 36 & $(59.01)$ & 0.0152 \\
4 & WB & 46 & $(56.78)$ & 35 & $(43.20)$ & 0.0750 \\
5 & Positive & \multicolumn{2}{c}{$32.69 \mathrm{~b}$} & & $67.29 \mathrm{a}$ & \\
\hline \multirow{2}{*}{ Overall mean } & Negative & \multicolumn{2}{c}{$67.31 \mathrm{a}$} & \multicolumn{2}{c}{$32.70 \mathrm{~b}$} & \\
& &
\end{tabular}

*letters in the row differ at 5\% significance by Tukey's test.

A higher percentage of seroconversions was also identified in animals born to dams that were seropositive at birth $(n=55)$ when compared with those born to seronegative dams $(n=21)(\mathrm{p}<0.001)$. In 181 animals, it was not possible to determine the real serological status of the dam at the time of kidding due to the long interval between parturition and the last serological examination performed.

In the initial serological examination, five sires were identified as seropositive. Subsequently, three animals turned positive, one of which was introduced to the farm after the program began. All seroconversions were detected by WB; two of them were observed in the third examination and one in the fourth.
A total of 172 animals were discarded during the study, the majority of which were positive $(140 / 175) \quad(p<0.0001)$, versus $35 / 175$ negative. The most common cause of discard was reduced milk yield, followed by reproductive problems and health problems.

The bandages used on the teats before kidding proved to be efficient to prevent the colostrum ingestion. However, the separation of the offspring from the dams immediately after birth was compromised in situations in which the births occurred outside the employees' working hours. Strict inspection was necessary to make the necessary adjustments for control in the work routine already in force on the farm. 


\section{Discussion}

The results found in the initial serological examination showed that there was an important spread of the CAE virus in the herd. This can be explained by the lack of any control measures for the disease in the herd even in the presence of animals with clinical signs characteristic of the disease and complaint by the owner about its productive impact. The positivity found in this examination characterized the herd as having intermediate serological prevalence, considering that control programs classify prevalence as high $(>70 \%)$, intermediate $(40-69 \%)$, low (10-39\%) or negative (Reina et al., 2009). Intensive management, herd size and production aptitude were likely factors that contributed to the spread of the virus. According to Ghanem et al. (2009), a high prevalence may be associated with close contact between animals.

The identification of new cases in the subsequent serological examinations showed that the infections persisted. Nonetheless, it must be considered that some of these animals might have become infected before the measures were established and did not yet have antibody titers that could be identified. According to Hanson, Hydbring, \& Olsson (1996), low levels of antibodies, intermittent seropositive reactions and delayed seroconversion are the major obstacles for the control of CAE. However, the significant percentage of seroconversions in animals born after the start of the program demonstrates that the infections continued to occur even after the establishment of the measures indicated for the control of the disease.

The identification of new infections even when the interval between serological examinations was short (as in the third evaluation, which was done only 87 days after the second) is worrying, as it suggests that even when positive and negative herds are segregated, positive and negative animals coexist when the interval between serological tests increases. This result shows that tests for the identification of positive animals must be performed in a shorter time interval. Rowe and East (1997) had already demonstrated the importance of understanding transmission routes and of early detection of new and latent cases. Gouveia (2012) presented the periodicity of examinations as a fundamental requirement for the success of control programs, which can vary according to the initial serological prevalence of the herds and the stage of development of the adopted health program. In more advanced stages, less periodicity in serological tests is recommended, with bimonthly or quarterly exams.

Based on the Kappa index, the agreement between the serological tests was considered almost perfect (Thrusfield, 2005), indicating that there was no difference between the tests.

The lack of seroconversions in the age group of 6 to 12 months, in serological examinations 1 and 2, may be related to the use of the AGID, since positive animals started to be identified when WB started to be used. The WB test provides better results in detecting the disease when compared with AGID (Rodrigues et al., 2014). In a study that demonstrated vertical transmission of the virus to goats, no animal was positive by serological methods during the 12 months of evaluation, whereas $50 \%$ of the evaluated animals were positive in polymerase chain reaction (PCR) (Hasegawa et al., 2017). In the early stages of infection, the concentration of antibodies is low or even non-existent (Adams et al., 1983) and, in some cases, antibodies can be detected only 18 months after molecular detection (Wagter, Jansen, Bleumink-Pluym, Lenstra \& Houwers, 1998).

The high number of seroconversions identified in the animals aged between 13 and 36 months demonstrates the importance of horizontal transmission of the virus. This may have occurred at the time of kidding through contact between positive dams and offspring due to failure in separation; by the coexistence between offspring of negative and positive dams in the same facilities with a high animal density; or inability of the serological tests 
to identify animals in the initial stage of infection. In addition, this age group comprised young does able to reproduce, which were transferred to facilities close to the positive animals to start the reproductive season and remained there. Despite being separated from seropositive animals by a distance of $2 \mathrm{~m}$, which has been confirmed as satisfactory in other studies (Adams et al., 1983; Robinson \& Ellis, 1986), and MAPA recommending a distance of $5 \mathrm{~m}$, it should be considered that, in the available literature, programs considered to achieve the best success emphasize strict care in separating animals, including the use of walls (Péretz et al., 1994) or separating positive and negative animals on different farms (Konishi et al., 2011; Pérez et al., 2013). It must also be considered that the possibility of infection at that moment is aggravated by the constant circulation of the same employees among positive and negative animals.

The high levels of seroconversion identified in the lactating does raises the possibility of infection at the time of milking. Although the negative does were milked first, animals that become infected can remain in the group of negative animals until they are seroconverted and can be an important source of contamination at the time of milking. An experimental study showed that intramammary inoculation of allogeneic cells infected with the CAE virus, at any stage of the milking cycle, leads to generalization of the infection, and infected cells can be detected even before the expression of specific antibodies (Lerondelle, Greenland, Jane, \& Mornex, 1995).

An important percentage of positive males was identified at the beginning of the study, despite the fact that they were raised in individual pens. According to Nowicka et al. (2015), because seropositive males can facilitate the spread of smallruminant lentivirus infection, their presence should be considered a risk factor. However, further studies are needed to understand the form of contamination of this animal category, since no transmission of the virus from females to males has been reported
(Blacklaws et al., 2004). The seroconversion of three sires is worrying, especially if we consider that they were reared separately and only mounted females with the same serological status. The possibility that males are becoming infected with females classified as negative in the last serological evaluation, but which became infected after the test was carried out, should be considered. This may even be aggravated by the permanence of the sires with the females during the breeding season, which is rather long (42 days).

At the end of the study period, despite the implementation of control measures and the disposal of a considerable number of positive animals, the initial and final rates of seroprevalence were close, due to the new seroconversions observed. Some control programs are based on the use of periodic serological examinations and the slaughter of positive animals (Gufler, 2013). Undoubtedly, eliminating reactive animals reduces the chance of horizontal transmission. However, for herds with high serological prevalence, additional control measures must be employed.

The greater number of seroconversions observed in the offspring from infected dams in this study and the fact that the kids did not effectively ingest colostrum from the dams - which is considered one of the most important factors in the infection of new animals - demonstrates the importance of horizontal and transplacental transmission of the virus. Though less important than infection via colostrum/ milk, transmission through other secretions such as feces, saliva, respiratory or urogenital secretions and even placentae contaminated with maternal blood should be considered (Adams et al., 1983; Peterhans et al., 2004). It is observed that even if the recommended control measures are adopted, the possibilities of horizontal contamination in intensive farming systems are very present. According to Minguijón et al. (2015), horizontal transmission has been underestimated in relation to lactogenic transmission, possibly being even more important than the latter. In a study with sheep, 
Broughton-Neiswanger et al. (2010) identified that $85.7 \%$ to $90 \%$ of the offspring that became infected contracted the disease through horizontal transmission. Transplacental transmission has been reported, and the importance of this route was evidenced in a study conducted by Hasegawa et al. (2017). Preventing the contact between infected dams and their offspring at the time of kidding is a difficult measure to implement, since, in most cases, farms do not have enough manpower to perform this task. This is especially true when the births take place at night or during dawn, which is undoubtedly an obstacle to disease control. This contact, even for a short period, can lead to infection of the offspring.

Another aspect that should be considered important on farms that aim to control CAE is not to allow offspring from positive and negative dams to remain in the same facilities after birth as well as separate them according to the serological status of the dams since birth. Animals that were eventually infected vertically can transmit the virus to other animals horizontally, as strong current evidence points to vertical transmission of the virus (Hasegawa et al., 2017). This measure is not determined in control programs, with emphasis being placed only on the separation between the kid and the dam. In this study, the fact that this separation was not carried out may have led kids infected in intrauterine life, or shortly after birth, to coexist for months with negative kids, as these animals remained together until they reached the appropriate age for the first serological examination. This may have favored the infection of new animals, a situation that was aggravated by the close contact of the young goats, which remained in collective cages with up to 20 animals. For farms that aim to control CAE, it is recommended to concentrate the kiddings at certain times of the year and that, in these periods, full attention be given to the monitoring of births. For these measures to be executed, the costs of hiring provisional employees should be taken into account.

Although the time of approximately three years proposed for the evaluation of the program is relatively short, it can be inferred that the results were not satisfactory and suggest that there are forms and moments of infection of new animals yet to be elucidated.

Models of control programs have been reported, but the difficulty in eradicating the disease is notable (Pérez et al., 2013; Gufler, 2013), even in long-term control programs (Kaba et al., 2011). In a control program in Poland, seroprevalence before the program was $75 \%$, which declined to $26.4 \%$ in a period of five years, with an annual drop of $9.8 \%$. However, in the last stage of the study, seroprevalence stabilized at approximately 30\% and the disease became endemic (Kaba et al., 2011). Conversely, eradication was achieved on a dairy farm in Japan over a four-year period. Unlike traditional control programs, the authors considered the initial herd to be entirely positive and each generation of animals born was kept in different locations and tested periodically using AGID and polymerase chain reaction (PCR). The control program was also based on the removal of newborns shortly after birth and the slaughter of positive animals in periodic serological examinations (Konishi et al., 2011).

A contextual analysis of the results obtained in this study with the characteristics of the herd in which the control program was established, which are similar to those encountered on many farms in Brazil, reveals the existence of several limitations to the establishment of measures already identified as necessary. In addition, other control measures must be included, namely, use of diagnostic tests with less frequency in the herd; use of high sensitivity tests on animals up to 12 months old; immediate separation of the offspring from the dams at birth; separation of the kids according to the serological status of the dams; inclusion of offspring from unsupervised births in the group of offspring from positive dams; and keeping positive and negative animals on different farms or at a considerable distance. Consideration should also be given to the possibility of different employees handling positive and negative animals. 


\section{Conclusions}

In the first study conducted in Brazil aiming to evaluate the results of CAE control measures in a commercial herd, the control measures were found not to contribute to reducing new cases. We emphasize the importance of considering other aspects related to the transmission of the disease so that new measures are implemented in addition to those already reported in the literature. However, in herds for which there is an intention to establish a control, it is important to determine whether the productive losses associated with the disease are greater than the costs incurred in the implementation of more efficient measures.

\section{Acknowledgments}

Thanks are due to the Brazilian Agricultural Research Corporation Embrapa Goat and Sheep.

\section{References}

Adams, D. S., Klevjer-Anderson, P., Carlson, B. S., \& Mcguire, T. C. (1983). Transmission and control of caprine arthritis-encephalitis virus. American Journal of Veterinary Research, 44(9), 1670-1675. Recovered from: https://europepmc.org/article/ $\mathrm{med} / 6625321$

Alves, J. R. A., Limeira, C. H., Lima, G. M. S., Pinheiro, R. R., Alves, F. S. F., Santos, V. W. S.,... Alves, C. J. (2017). Epidemiological characterization and risk factors associated with lentiviral infection of small ruminants at animal fairs in the semiarid sertão region of Pernambuco, Brazilian semiarid. Semina: Ciências Agrárias, 38(4), 1875-1886. doi: 10.5433/1679-0359.2017v38n4p1875

Azevedo, D. A. A., Santos, V. W. S., Sousa, A. L. M., Peixoto, R. M., Pinheiro, R. R., Andrioli, A., \& Teixeira, M. F. S. (2017). Small ruminant lentiviruses: economic and productive losses, consequences of the disease. Arquivos do Instituto Biológico, 84, 1-10. doi: 10.1590/1808-1657000552016. Recovered from: https://ainfo.cnptia.embrapa.br/digital/ bitstream/item/168961/1/CNPC-2017-Small.pdf

Blacklaws, B. A., Berriatua, E., Torsteinsdottir, S., Watt, N. J., Andres, D., Klein, D., \& Harkiss, G. D. (2004). Transmission of small ruminant lentiviruses.
Veterinary Microbiology, 101(3), 199-208. doi: 10. 1016/j.vetmic.2004.04.006

Broughton-Neiswanger, L. E., White, S. N., Knowles, D. P., Mousel, M. R., Lewis, G. S., Herndon, D. R., \& Herrmann-Hoesing, L. M. (2010). Nonmaternal transmission is the major mode of ovine lentivírus transmission in a ewe flock: a molecular epidemiology study. Infection, Genetics and Evolution, Irvine, 10(7), 998-1007. doi: 10.1016/j. meegid.2010.06.007

Callado, A. K. C., Castro, R. S., Nascimento, S. A., SilvaRodrigues, M. I. M., Pinto, J. H., Jr., \& Teixeira, M. F. S. (1999). Preliminary characterization of the infection of synovial membrane cells by brazilian samples of small ruminants lentiviruses. Ciência Veterinária nos Trópicos, 2(3), 152-159. Recovered from: http://www.rcvt.org.br/volumes/ volume_2,numero_3,setembro_dezembro,1999.pdf

Cheevers, W., McGuire, T., Norton, L. K., Cordery-Cotter, R., \& Knowles, D. (1993). Failure of neutralizing to regulate CAE lentivirus expression in vivo. Virology, 196(2), 835-839. doi: 10.1006/viro.1993.1542

Cortez-Moreira, M., Oelemann, W. M. R., \& Lilenbaum, W. (2005). Comparison of serological methods for the diagnostic of caprine arthritis-encephalitis (CAE) in Rio de Janeiro, Brazil. Brazilian Journal of Microbiology, 36(1), 48-50. doi: 10.1590/S151783822005000100010

Ghanem, Y. M., EL-Khodery, S. A., Saad, A. A., Elragaby, S. A., Abdelkader, A. H., \& Heybe, A. (2009). Prevalence and risk factors of caprine arthritis encephalitis virus infection (CAEV) in Northern Somalia. Small Ruminant Research, 85, 42-148. doi: 10.1016/j.smallrumres.2009.09.005. Recovered from: https://www.sciencedirect.com/ science/article/abs/pii/S0921448809001631

Gouveia, A. M. G. (2012). Lentiviroses de pequenos ruminantes. Cadernos Técnicos de Veterinária e Zootecnia, 64, 46-59. doi: 10.13140/ RG.2.1.5096.6489. Recovered from: https://issuu. com/escolade veterinariaufmg/docs/caderno_ tecnico_64_retroviroses_ani

Gufler, H. (2013). Challenges of the Caprine Lentivirus control programme in South Tyrol, Italy. Small Ruminant Research, 110, 112-114. doi: 10.1016/j. smallrumres.2012.11.016. Recovered from: https:// www.sciencedirect.com/science/article/abs/pii/ S0921448812004762

Hanson, J., Hydbring, E., \& Olsson, K. (1996). Along term study of goats naturally 362 infected with 
caprine arthritis-encephalitis virus. Acta Veterinaria Scandinavica, 37(1), 31-39. Recovered from: https:// pubmed.ncbi.nlm.nih.gov/8659344/

Hasegawa, M. Y., Souza, M. C. C., Lara, H., Villa Lobos, E. M. C., Gaeta, N. C., Hayashi, M.,.. Gregory, L. (2017). An experimental study on the vertical transmission of caprine arthritis-encephalitis virus from naturally infected females to their offspring. Small Ruminant Research, 149, 23-27. doi: 10.1080/ 14622200410001676305. Recovered from: https:// www.sciencedirect.com/science/article/abs/pii/S09 21448817300184

International Committee on Taxonomy of Viruses (2019). Virus taxonomy: 2019 release. London: Microbiology Society. Retrieved from http:// https:// talk.ictvonline.org/taxonomy/

Kaba, J., Bagnicka, E., Czopowicz, M., Nowicki, M., Witkowski, L., \& Szaluoe-Jordanow, O. (2011). Long-term study on the spread of caprine arthritisencephalitis in a goat herd. Central European Journal of Immunology, 36(3), 170-173. Recovered from: https://www.termedia.pl/-Experimentalimmunology-r-n-r-nLong-term-study-on-thespread-of-caprine-arthritis-encephalitis-in-a-goatherd, 10,17506,1,1.html

Konishi, M., Nagurab, Y., Takeib, N., Fujita, M., Hayashic, K., Tsukiokad, M.,.. Murakamia, K. (2011). Combined eradication strategy for CAE in a dairy goat farm in Japan. Small Ruminant Research, 99, 65-71. doi: 10.1016/j.smallrumres.2011.03.051. Recovered from: https://www.sciencedirect.com/ science/ article/abs/pii/S092144881100126X

Lara, M. C. C. S. H., Villalobos, E. M. C., Cunha, E. M. S., Chiebao, D., Gabriel, F. H., Paulin, L. M.,... Cardoso, M. V. (2013). Inquérito sorológico de lentiviroses de pequenos ruminantes (Maedi-Visna e artrite-encefalite caprina) no estado de São Paulo. Brazilian Journal Veterinary Research and Animal Science, 50(1), 18-25. Recovered from: http://www. revistas.usp.br/bjvras/article/view/55820/59436

Lerondelle, C., Greenland, T., Jane, M., \& Mornex, J. F. (1995). Infection of lactating goats by mammary instillation of cell-borne caprine arthritis-encephalitis virus. Journal of Dairy Science, 78(4), 850-855. doi: 10.3168/jds.S0022-0302(95)76697-8

Lima, C. C. V., Costa, J. N., Souza, T. S., Martinez, P. M., Costa, A. O., Neto, Azevedo, D. A. A.,... Brito, R. L. L. de. (2013a). Imunodiagnóstico para a artriteencefalite caprina em rebanhos do semiárido baiano, Brasil. Revista Brasileira de Medicina Veterinária, 35(4), 358-364. Recovered from: https://ainfo. cnptia.embrapa.br/digital/bitstream/item/93417/1/ api-Imunodiagnostico-para-artrite.pdf

Lima, C. C. V., Costa, J. N., Souza, T. S., Martinez, P., Costa, A. O., Neto, Anunciação, A. V. M.,... Pinheiro, R. R. (2013b). Inquérito soroepidemiológico do lentivírus caprino e perfil das criações de caprinos na região do Baixo Médio São Francisco (BA). Arquivos do Instituto Biológico, 80(3), 288-296. doi: 10.1590/S1808-16572013000300005

Madureira, K. M., \& Gomes, V. (2007). Prevalência da artrite encefalite caprina (CAE) em propriedades leiterias do Estado de São Paulo. Revista Brasileira de Ciência Veterinária, 5, 86-90. Recovered from: https://www.researchgate.net/profile/Viviani_ Gomes/publication/228997592_Prevalencia_ da_artrite_encefalite_caprina_CAE_em_ propriedades_leiteiras_do_Estado_de_Sao_Paulo/ links/0912f506418ebc 5 feb000000/Prevalencia-daartrite-encefalite-caprina-CAE-em-propriedadesleiteiras-do-Estado-de-Sao-Paulo.pdf

Melo, A. C. M., \& Franke, C. R. (1997). Soroprevalência da infecção pelo vírus da artrite-encefalite caprina (CAEV) no rebanho de caprinos leiteiros da região da grande Fortaleza, Ceará, Brasil. Ciência Rural, 27(1), 113-117. doi: 10.1590/S0103-84781997000100019

Minguijón, E., Reina, R., Pérez, M., Polledod, L., Villoria, M., Ramírez, H.,... Justea, R. A. (2015). Small ruminant lentivirus infections and diseases. Veterinary Microbiology, $181\left(\mathrm{n}^{\circ}\right), \quad 75-89$. doi: 10.1016/ j.vetmic.2015.0. Recovered from: https://www.sciencedirect.com/science/article/pii/ S0378113515003156

Moojen, V., Soares, H. C., Ravazzolo, A. P., Pizzol, M., \& Gomes, M. (1986). Evidência de infecção pelo lentivirus (maedi/visna - Artrite-encefalite Caprina) em caprinos no Rio Grande do Sul, Brasil. Arquivos da Faculdade de Medicina Veterinária UFRGS, 1(n $\left.{ }^{\circ}\right), 77-78$. Recovered from: http:/www.ufrgs.br/ actavet/1-29/1986.pdf

Narayan, O., Joag, S. V., Chebloune, Y., Zink, M. C., \& Clements, J. E. (1997). Visnamaedi: the prototype lentiviral disease. In N. Nathanson (Ed.), Viral pathogenesis (pp. 657-668). Philadelphia: Lippincott-Raven.

Nascimento-Penido, P. M. P., Penido, A. O., Galinari, G. C. F., Heinemanns, M. B., \& Leite, R. C. (2017). Ocorrência do vírus da artrite encefalite caprina (CAEV) em cabras leiteiras produzidas em sistema intensivo confinado no estado de Minas Gerais. Pesquisa Veterinária Brasileira, 37(6), 577-581. doi: 10.1590/S0100-736X2017000600007 
Nord, K., Løken, T., \& Orten, Å. (1998). Control of caprine arthritis-encephalitis virus infection in three Norwegian goat herds. Small Ruminant Research, 28, 109-114. doi: 10.1016/S0921-4488(97)000795. Recovered from: https://www.sciencedirect.com/ science/article/abs/pii/S0921448897000795

Nowicka, D., Czopowicz, M., Szaluś-Jordanow, O., Witkowski, L., Bagnicka, E., \& Kaba, J. (2015). Seropositive bucks and within-herd prevalence of small ruminant lentivirus infection. Central European Journal of Immunology, 40(3), 283-286. doi: 10.5114/ceji.2015.54587

Péretz, G., Bugnard, F., \& Calavas, D. (1994). Study of a prevention programme for caprine arthritisencephalitis. Veterinary Research, 25, 322-326. Recovered from: https://hal.archives-ouvertes.fr/hal00902218/document

Pérez, M., Muñoz, J. A., Biescas, E., Salazar, E., Bolea, R., Andrés, D.,... Luján, L. (2013). Successful Visna/maedi control in a highly infected ovine dairy flock using serologic segregation and management strategies. Preventive Veterinary Medicine, 112, 423-427. doi: 10.1016/j. prevetmed.2013.07.019. Recovered from: https:// www.sciencedirect.com/science/article/pii/ S0167587713002468?via\%3Dihub

Peterhans, E., Greenland, T., Badiola, J., Harkiss, G., Bertoni, G., Amorena, B.,... Pépin, M. (2004). Routes of transmission and consequences of small ruminant lentiviruses (SRLVs) infection and eradication schemes. Veterinary Research, 35(3), 257-274. doi: 10.1051/vetres:2004014

Pinheiro, R. R., Ximenes, L. J. F., Andrioli, A., \& Texeira, M. F. S. (2009). Lentivírus de pequenos ruminantes: diagnóstico, prevenção e vacinas. In Ximenes, L. J. F., Martins, G. A., Narciso Sobrinho, J. \& Carvalho, J. M. M. de (Eds.), As ações do Banco do Nordeste do Brasil em $P$ \& D na arte da pecuária de ovinos e caprinos no Nordeste brasileiro (pp. 305-328). Fortaleza: Banco do Nordeste do Brasil.

Portaria $n^{\circ} 103$, de 7 de dezembro de 2004 (2004). Plano Nacional de Vigilância e controle das lentiviroses de pequenos ruminantes. Ministério da Agricultura Pecuária e Abastecimento. Brasília: Ministério da Agricultura, Pecuária e Abastecimento. Recuperado de http://extranet.agricultura.gov.br/sislegis

$\mathrm{R}$ Core Team (2018). R: a language and environment for statistical computing. Vienna: R Foundation for Statistical Computing. Retrieved from https:// www.R-project. org/
Reilly, L. K., Baird, A. N., \& Pugh, D. G. (2012). Diseases of the musculoskeletal system. In Pugh, D. G. \& Baird, A. N. (Eds.), Sheep and goat medicine (pp. 291-324). Maryland Heights: Saunders.

Reina, R., Berriatua, E., Luja, N. L., Juste, R., Sánchez, A., De Andrés, D., \& Amoren, B. (2009). Prevention strategies against small ruminant lentiviruses: An update. The Veterinary Journal, 182(1), 31-37. doi: 10.1016/j.tvj1.2008.05.008

Rimstad, E., East, N., De Rock, E., Higgins, J., \& Pedersen, N. C. (1994). Detection of antibodies to caprine arthritis-encephalitis virus using recombinant gag proteins. Archives of Virology, 134, 345-356. doi: 10.1007/bf01310572. Recovered from: https://ink. springer.com/content/pdf/10.1007/BF01310572.pdf

Rizzo, H., Jesus, T. K. S., Castro, R. S., Pinheiro, J. W., Jr., Soares, L. L. S., Oliveira, C. C. M.,... Silva, T. R. (2018). Ocorrência e fatores de risco associados à infecção por lentivírus de pequenos ruminantes no Estado de Sergipe. Pesquisa Veterinária Brasileira, 38(6), 1043-1050. doi: 10.1590/1678-5150-pvb5363

Robinson, W. F., \& Ellis, T. M. (1986). Caprine arthritisencephalitis virus infection: from recognition to eradication. Australian Veterinary Journal, 63(8), 237-241. doi: 10.1111/j.1751-0813.1986.tb02983.x

Rodrigues, A. S., Brito, R. L. L., Pinheiro, R. R., Dias, R. P., Alves, S. M., Souza, T. S.,... Teixeira, M. F. S. (2014). Padronização do Elisa indireto e Western Blot para diagnóstico da artrite-encefalite caprina. Arquivo Brasileiro de Medicina Veterinária e Zootecnia, 66(2), 417-424. doi: 10.1590/167841626303.

Rodrigues, A. S., Pinheiro, R. R., Brito, R. L. L., Andrioli, A., Oliveira, E. L., Sider, L. H.,... Texeira, M. F. S. (2018). Avaliação de um controle estratégico da Artrite Encefalite Caprina em rebanho caprino leiteiro. Arquivo Brasileiro de Medicina Veterinária e Zootecnia, 70(1), 139-146. doi: 10.1590/16784162-9537.

Rowe, J. D., \& East, N. E. (1997). Risk factors for transmission and methods for control of caprinearthritis-encephalitis virus infection. Veterinary Clinics of North America: Food Animal Practice, 13(1), 35-53. doi: 10.1016/S07490720(15)30363-7

Silva, J. G., Araújo, P. B., Souza, W. M. A., Silva, L. C., Jr., Alencar, S. P., Nascimento, S. A.,... Coelho, M. C. O. C. (2012). Soroprevalência de Lentivirus em caprinos leiteiros. Medicina Veterinária, 6(3), 
9-12. Recovered from: http://www.journals.ufrpe.br/ index.php/medicinaveterinaria/article/view/614/493

Smith, M. C., \& Sherman, D. M. (2009). Musculoskeletal system. In Smith, M. C \& Sherman, D. M (Eds,), Goat medicine (pp. 96-106). Hoboken: WileyBlackwell.

Souza, K. C., Andrioli, A., Sider, L. H., Pinheiro, R. R., Bezerra, R. Q., Jr., Peixoto, R. M., \& Teixeira, M. F. S. (2015). Detecção de sequências do DNA proviral do vírus da Artrite Encefalite Caprina em saliva. Acta Scientiae Veterinariae, 43, 1-6. Recovered from: https://ainfo.cnptia.embrapa.br/digital/bitstream/ item/136302/1/cnpc-2015-Deteccao.pdf

Souza, K. C., Pinheiro, R. R., Santos, D. O., Brito, R. L. L., Rodrigues, A. S., Sidera, L. H.,... Andrioli, A. (2013). Transmission of the caprine arthritisencephalitis virus through artificial insemination. Small Ruminant Research, 109, 193-198. doi: 10.1016/j.smallrumres.2012.07.031 Recovered from: https:// reader.elsevier.com/reader/sd/pii/S09 21448812003549?token=19E7D59E27DB53B1EE 9AE36EF8D2335D40364D62F7AE4F9E6F61ED0 5E9F7171FD6764CD01C7C016A0E361C633986B $4 \mathrm{AB}$

Stachissini, A. V. M., Modolo, J. R., Castro, R. S., Leite, B. L. S., Araújo, J. P., Jr., \& Padovani, C. R. (2007). Controle da Artrite-Encefalite Caprina, em um capril comercial e endemicamente contaminado. Brazilian Journal of Veterinary Research and Animal Science, 44(1), 40-43. Recovered from: http:// www.revistas. usp.br/bjvras/article/view/26659/28442
Tavella, A., Bettini, A., Ceol, M., Zambotto, P., Stifter, E., Kusstatscher, N.,... Bertoni, G. (2017). Achievements of an eradication program against caprine arthritis encephalitis virus in South Tyrol, Italy. Veterinary Record, 182(2), 1-4. doi: 10.1136/vr.104503

Thrusfield, M. (2005). Veterinary epidemiology. Hoboken: Wiley-Blackwell.

Villoria, M., Leginagoikoa, I., Luján, L., Pérez, M., Salazar, E., Berriatua, E.,... Minguijón, E. (2013). Detection of small ruminant Lentivirus in environmental samples of air and water. Small Ruminant Research, 110, 155-160. doi: 10.1016/j. smallrumres.2012.11.025. Recovered from: https:// www. science direct.com/science/article/abs/pii/ S0921448812004853

Wagter, L. H., Jansen, A., Bleumink-Pluym, N. M., Lenstra, J. A., \& Houwers, D. J. (1998). PCR detection of lentiviral GAG segment DNA in the white blood cells of sheep and goats. Veterinary Research Communications, 22(5), 355-362. doi: 10.1023/A:1006181307002 
